\title{
ESP in China: Successes, Challenges, and Emerging Trends
}

\author{
Vinita Gaikwad \\ Kean University, Wenzhou, China
}

\begin{abstract}
English for specific purposes (ESP) for undergraduate students is popular in China, although the understanding of what ESP means in China is different from how it is perceived in other countries. ESP in China was instituted as a result of needs-based studies and government initiatives; however, actual ESP practice is not without challenges and has seen both the extremes of failure and success. Currently, ESP is again being reformed and new disciplines stemming out of ESP are being introduced. This paper will outline some of successes and challenges ESP has faced in the past and discuss some of the emerging trends with reference to recent reforms introduced by the Ministry of Education.
\end{abstract}

Keywords: English for specific purposes (ESP), Business English, ESP in China, English language teaching (ELT) in China, ELT, English as a second language, English for academic purposes, teaching English language learners

\section{Introuduction}

English for specific purposes (ESP) offered along with, but sometimes confused with, English for occupational purposes (EOP) is commonly taught as College English in China. Many business professionals who wish to expand their businesses and are aware of the importance of using English for success in trade at a global scale take courses in English. They focus on developing their English skills in order to communicate with international business partners or clientele and are interested mostly in oral English. Professionals in other areas too, such as in the medical or engineering field, are equally interested in taking up short term English courses. These are taught by ESP professionals at universities or other institutions, such as language centers. It can be seen that ESP is a vast area in the field of language teaching in China; however, this paper focuses on ESP taught in China to college students. ESP has had varied meanings and purposes through the years and it is important to discuss briefly the background of ESP in China as documented by various local researchers in China.

\section{The Beginnings of ESP in China}

According to Zhang (2011), ESP in China consists of English language teaching (ELT) which is designed to meet the specified needs of the learner; related in content (i.e., in its themes and topics) to particular disciplines, occupations, and activities; centered on the language appropriate to those activities in syntax, lexis, discourse, semantics, and in the analysis of this discourse; and is in contrast to "General English" (Zhang, 2011). This definition is aligned with the definition given by ESP literature in the West.

College English came to be known as ESP due the shape the courses took corresponding to the demands of the society. According to Hao and Yin (2015), the teaching of "English as a foreign language to non-English majors at the tertiary level in mainland China is referred to as College English." According to them, this course

Vinita Gaikwad, Ph.D., assistant professor, School of English Studies, Kean University. 
has a special position in Chinese higher education, because it is meant to equip future professionals with the language skills necessary for international communication, and has therefore attracted large investment of time and money from both the government and individuals involved.

The concept of ESP in College English evolved from English of Foreign Trade to what was later called Business English. Zhu, Peng, Zhang, and Yi (2011) traced the beginnings of Business English in China to the 1950s when high education institutions introduced Foreign Trade English which mainly included courses, such as English for Electronic Communication, Selected Readings of the Western Paper, Oral English of Foreign Trade, etc.. In 1990s, due to the globalization and rapid rise of Chinese economy as well as increase in foreign trade, Business English grew in demand and soon began to replace Foreign Trade English. In their paper, in 2015, Hao and Yin (2015) referred to the beginnings of ESP in the 1960s and 1970s in the western countries on the principle that English was becoming a lingua franca in economy, science and technology, and culture exchanges. They mentioned that this idea had a strong impact on the foreign language teaching in China in the 1980s when a variety of ESP courses, such as English for Metallurgy, English for Medicine, or English for Hydropower, and so on were put on the shoulders of the college English teachers. So, in the mid-1980s, two different College English Teaching Syllabuses were introduced, one for Liberal Arts in 1985 and the other for Science and Technology in 1986 (Hao \& Yin, 2015).

In 2004, the Ministry of Education issued College English Course Teaching Requirements that set new guidelines for the curriculum and pedagogy. In recent years, signs of another round of reform are arising which is content-driven and characterized by ESP (Hao \& Yin, 2015). In the year 2007, a new discipline was introduced in the system which came to be known as Business English discipline. It emphasized on the formation of a completely new disciplinary theory and the establishment of a separate disciplinary system from the past applied linguistics, which constituted the unique development route different from any other country (Zhu et al., 2011). For example, in some institutions, such as Guangdong University of Foreign Studies, a new school called the School of English for Business specializing in teaching business English undergraduate and postgraduate programs was established with the integration of teachers from Faculty of English Language and Culture, School of Law, and School of International Trade and Economics (Zhu et al., 2011). Currently, several undergraduate programs are offering a major in Business English including those offered by Sino-foreign collaborative universities.

\section{Issues With ESP in China}

In order to gauge the success of these programs, the reasons for the failure of ESP in the 1980s in China must be considered firstly. According to Hao and Yin (2015), some of the reasons for this failure were, firstly, the fact that the College English Tests (CETs) focused on General English and the subject content was from the humanities. Secondly, ESP was associated with courses and course books, such as English for Chemical Engineering, English for Mining, and so on. The fact that these courses were designed to teach the subject content rather than the language made it difficult for the language teachers whose education background was mainly of humanities. Thirdly, the students in the mid-1980s were not prepared to take subject-based English courses, because their basic English skills were still very poor. These issues resulted in a strong dislike for ESP and continued favor of General English. Chinese learners' major purpose of English learning is to be able to use English as a tool to obtain information in their special field and to express their special ideas in English (Hao \& Yin, 2015). 
Zhang (2011) also mentioned that two years of learning English in college do not help lay a solid foundation. In their third year, all non-English majors have their subject-specific course which is called ESP. For example, students majoring in Material Engineering have their own English course in this field and students majoring in Geology have their ESP class. In this case, it is not uncommon that the ESP teachers usually specialized subject experts have not been trained in the methods of language teaching. As Zhang (2011) said that the major teaching approach is grammar-translation, which focuses on the analysis of English sentences in terms of grammar and then translates them into Chinese. It is teacher-centered and students are passive in class. Consequently, the English that students learn is an ossified language, and thus, they are unable to discuss the work-related matters in English on which they spend much time. The teaching materials are also not satisfactory in terms of the balance between language learning and subject learning (Zhang, 2011).

However, as mentioned above, ESP has returned and has become the focus of all ELT in China today. At present, Business English in China is highly recognized in the society as one of the most popular disciplines rather than an approach to learning English. Statistics show that the number of universities that have opened Business English major courses exceeds 800, and the schooling levels, majors, and degrees are more and more diversified. Graduates of Business English are very popular in Multinational Corporations (MNCs) and other International Business Enterprises (Zhu et al., 2011).

Another researcher, Li (n.d.) described how after China's entry into the World Trade Organization (WTO), Business English seems to have taken a lead in teaching ESP and different kinds of Business English courses and books have appeared in the market. In addition, the popularity of Cambridge Business English Certificate (BEC), an international Business English examination, has led to the quick expansion of Business English (Li, n.d.). However, Li rightly pointed out the problems with wrongly focusing on the business content more than the language that carries the content. This led more to business knowledge acquisition rather than Business English acquisition.

Accrding to Hao and Yin (2015), in 2004, when the Ministry of Education decided that Chinese higher education should also participate in the internationalization process, it led to the reforms in the teaching of General English to ESP which then resulted in the shift in emphasis from skills to content, so as to prepare students not only for bilingual subject courses, but also for their future professional careers. At the same time, many teachers of ESP are for the opinion that General English is still necessary for students before they move on to ESP. A research conducted by Cai, Wang, Pang, and Xue (as cited in Hao \& Yin, 2015) pointed out that $90.8 \%$ of the students who passed their CETs claim that they still need to learn English and are not confident in using the language for communication at their work place.

Zhang (2011) pointed out that majority of specialized information available in any media is in English. Non-specialized English majors, therefore, are faced with the difficulty of unemployment upon graduation. An issue related to the instruction of specialized English impacts academic professionals, and the ever increasing need of Chinese scholars and specialists to publish in international journals, the majority of which are published in English. They turn to the teachers of English. While proficient in English, however, without knowledge in the scholar's specialized field, English teachers cannot translate such works effectively, either.

\section{New Developments for ESP in China}

Business English is currently one of the areas of growth in ESP (Ellis \& Johnson, 1994). In recent years, researchers have made ongoing researches into the new development of Business English as a sub-branch of 
ESP in China since the Ministry of Education approved Business English as a formalized new discipline in 2007. Business English in China has been highly recognized in the society as one of the most popular disciplines rather than merely an approach to learning English (Zhu et al., 2011). Li (n.d.) also stated that some universities in China offer Business English major undergraduate programs and a few universities even offer Business English major postgraduate programs. Some have proposed that Business English or International Business English (IBE) be developed into an independent discipline although it is generally accepted as one branch of ESP.

Business English in China has now become a new cross-discipline which applies theories and methods of linguistics, culture studies, management theories, economics, and culture in international communication (Zhu et al., 2011). The new model proposes a course design that includes $70 \%$ of English language courses and 30\% business courses that include business theories and practices. Teaching business courses in English or bilingual language has become the main mode of Business English teaching in Chinese universities and includes teachers who have completed both English and business majors (as double major) or teachers with either English major who have fairly good business management knowledge base or are business majors with fairly good English proficiency.

\section{The Current Challenge}

This proposed scheme is fast becoming popular and being adopted by several sino-foreign universities as well. However, there are doubts that this is a solution to the existing issues with ESP. For one, there is a possibility that a course design that offers $70 \%$ English language emphasis (thus not making it a $100 \%$ ) and $30 \%$ emphasis on business content (surely much less that what is expected from a business graduate) will result in students neither proficient in the English language nor in their content specific subjects. Moreover, courses in the two areas do not necessarily produce the desired qualification. For example, the outcome of a successful ESP course in Business English would be a graduate who would be familiar with the language conventions in the world of business, who would be proficient with the business discourse and apply the linguistic principles as analyzed by professionals in applied linguistics. This would lead to graduates of Business English discipline who would not only use the language well but will use it effectively in the specific business scenarios in the international corporate world.

Secondly, with regards to the debate on who should be considered as an expert teacher of this course- the English language teacher or the subject expert, it remains an issue to be dealt with. Kennedy (1983) described the status of ESP teachers as being in a "delicate position on the bridge between language and content" (p. 74). There has been many debates on this question but no satisfying answer has yet been found. Johns and Dudley-Evans (1993) found team-teaching extremely useful in their study. However, cooperation in teaching between the two types of instructors is important. Some have suggested both subject teacher and language teacher collaborate in such a way that they are both cross-trained. However, there are several problems associated with that too. Barron (2003) found that shared methodologies and even shared knowledge will not necessarily lead to successful collaboration. Barron (2003) reported a study that found collaboration among EAP professionals and content experts rather unsuccessful due to factors, such as conflicting course philosophies, unsuccessful negotiations, and students who did not appreciate collaboration and felt that the course was time-consuming and that they had to satisfy the expectations of two different ideologies.

As some professionals say, teachers should engage students to plan and carry out meaningful tasks and to 
solve problems that are relevant to the students' personal, academic, and professional goals (Wei, n.d.). This is an era where all the ELT teachers should be equipped with new innovative techniques to harness their pedagogical approach in the teaching both at the specialty level and at the technical level.

\section{Conclusion}

As an English for academic purposes (EAP) and ESP specialist practicing in China, the author realizes that the importance of ESP here and have been a part of the successes and challenges it has faced over the years. The latest reform in ELT in China of introducing Business English as a separate discipline on its own has gained popularity and is being seen as an answer to the issues in ESP as have been pointed above. However, there is a need to realize that there are problems here too. Unless appropriate curriculum is developed by merging the various business theories and other business content with the genre conventions, discourse analysis, lexico-grammatical conventions that feature in different genres and business discourse, etc., we will produce half-baked graduates who are neither proficient in the language nor in their knowledge of business. The content needs to be merged intelligently with the linguistic choices using various language resources to make true sense of the "Business English" discipline that any university offers. While the first generation of teachers in this program need to "cross learn" (Li, n.d.) from each other in the English, Applied Linguistics, and Business areas, the first graduates of this enriched programs will be true Business English graduates developing the necessary skills and theories to continue the trend further. That will be the real ESP through which students may aspire to reach their goals of making a mark in the international economy.

\section{References}

Barron, C. (2003). Problem-solving and EAP: Themes and issues in a collaborative teaching venture. English for Specific Purposes, 22(3), 297-314. doi: 10.1016/S0889-4906(02)00016-9

Dudley-Evans, T. (1993). Subject specificity in ESP: How much does the teacher need to know of the subject? ASp. La Revue Du GERAS, (1), 1-9. doi: 10.4000/asp.4354

Ellis, M., \& Johnson, C. (1994). Teaching Business English: An introduction to Business English for language teachers, trainers, and course organizers. Oxford: OUP.

Hao, X. Y., \& Yin, Z. P. (2015). College English teaching reform in China: An orientation toward ESP. International Journal of English Language Teaching, 2(2), 77-86. doi: 10.5430/ijelt.v2n2p77

Kennedy, C. (1983). An ESP approach to EFL/ESL teacher training. The ESP Journal, 2(1), 73-85. doi: 10.1016/0272-2380(83)90024-0

Li, L. X. (n.d.). Theoretical base and problems in Business English teaching in China. English for Specific Purposes World. Retrieved from http://www.esp-world.info/Articles_8/Li.htm

Wei, H. (n.d.). A tentative study on applying ESP in effective ELT in China. Retrieved from $\mathrm{http}: / /$ www.celea.org.cn/pastversion/lw/pdf/Hongwei.pdf

Zhang, J. (2011). Collaborative instructors and mixed learners: An English for specific purposes teaching model in China. Canadian Social Science, 7(5), 144-150. doi: 10.3968/J.css.1923669720110705.254

Zhu, W., Peng, C., Zhang, L., \& Yi, X. (2011). New developments of Business English from ESP in Chinạ. Theory and Practice in Language Studies, 1(4). doi: 10.4304/tpls.1.4.379-383 